Оригинални научни рад

616.89-008.442:331(497.11)

doi:10.5937/zrpfns52-17701

Zvezdan M. Đurić, Ph.D., Associate Professor

University of Priština

Faculty of Economics in Kosovska Mitrovica

zvezdan.djuric@bbs.edu.rs

Ivana M. Erić, Ph.D., Professor of Applied Studies

Belgrade Business Scholl

ivana.eric@bbs.edu.rs

\title{
THE INFLUENCE OF SEXUAL HARASSMENT ON BUSINESS RESULTS OF ENTERPRISES IN SERBIA THE LEGAL - BEHAVIORAL ASPECTS
}

Abstract: Sexual harassment at work is one of the biggest stressors, or an event that can disrupt normal functioning of individuals, which necessarily requiring bodily, psychological or behavioral adjustments, that can cause numerous consequences. It has a legal, moral and behavioral dimension. As a result of that, in the paper were presented the legal definitions, certain moral dilemmas and behavioral implications. Surely, viewed from the perspective of business implications, sexual harassment leaves negative psychological and general health consequences, as well as a significant decline in business performance. So, modern world organizations are trying to eradicate it. However, in many traditional environments, to which belong and ours these problems have not been considered as significant for many years. During the 2005, the Labor Law Republic of Serbia, Article 21 prohibited sexual harassment that happens in our country, which demonstrated good will to eradicate such ugly practices. An empirical research was conducted with the intention of determining the actual presence of sexual harassment and its implications for the business performance of organizations in Serbia.

Keywords: sexual harassment, legal regulations, health consequences, decline in business performance.

\section{INTRODUCTION}

Sexual harassment, unlike the prevailing opinion (women are at risk), can be carried out by both men and women. The point is that the harassment occurs 
due to the unequal distribution of power, that is appears to the subordinates. Similarly, as with domestic violence, all eyes were and still are turned into state organs. ${ }^{21}$ Unfortunately, the state itself, without the cooperation of the other party (actual victims, and not as sometimes a victim of manipulation ${ }^{22}$ ), is unable to fully protect victims. Most members of our community believe that sexual harassment is widespread in traditional environments. However, the actual data denies us. In the United States, sexual harassment is very much present, but it varying in degrees depending on activity and age. The most vulnerable are the workers from 24-40 years. The activities that lead to sexual harassment are: transport, trade, education and health. ${ }^{23}$ However, data shows that the number of sexual harassment cases decreases every year, because the penalties are draconian. According to the American Equal Rights Commission, 6758 applications were filed in 2016, of which $16.6 \%$ were filed by men, and in 2017, 6696 applications were received $16.5 \%$ retrospectively. ${ }^{24}$ By comparing with Europe for 1997, it was filed almost 15889 applications.

Unfortunately, even the Europe is not spared of sexual harassment. ${ }^{25}$ The average of sexual harassment for all countries is around 55\% for older than 15 years. The surprisingly leading are Sweden and Denmark ( $80 \%-100 \%$, the presence of sexual harassment). Following are Great Britain, France, Germany, Belgium and Norway (60\% -79\%). On the third place are Greece, Croatia, Hungary, Slovakia, Czech Republic, Slovenia, Spain, Italy, Scotland, Serbia, Bosnia and Herzegovina (40\% -59\%). Finally, the smallest incidence of sexual harassment is in Portugal, Austria, Romania, Poland and Lithuania (20\% -39\%). It is remarkably surprising that $75 \%$ of women's at the highest level in the organizational hierarchy had experienced some sort of sexual harassment. ${ }^{26}$

The given data provide a very real picture about of the presence of sexual harassment. However, the majority of the victims feel fear of reaction of their environment, although this is not their shame, also here is fear of demission, especially today when everywhere in the world announces a new wave of great economic crisis, need for justification to the partner, and more.

\footnotetext{
${ }^{21}$ Ljubomir S. Stajić, „Odgovor države na nasilje u porodici“, Zbornik radova Pravnog fakulteta u Novom Sadu (Zbornik radova PFNS) 3/2017, 664.

${ }^{22}$ An individual who plays the victim, in order to achieve personal interests.

${ }^{23}$ Joni Hersch, „Compensating differentials for sexual harassment”, American Economic Review 101.3, 2011, 633.

${ }^{24}$ US Equal Employment Opportunity Commision, https://www.eeoc.gov/eeoc/statistics/ enforcement/sexual_harassment_new.cfm, 21. may 2018.

${ }^{25}$ Europian Āgency for Fundamental Right, https://www.statista.com/chart/3345/sexualharassment-in-the-eu/, 22. may 2018.

${ }^{26}$ „Violence against women: an EU-wide survey. Main results report 2014”, Europian Union Agency Rights, http://fra.europa.eu/en/publication/2014/violence-against-women-eu-wide-survey-main-results-report, 23. may 2018.
} 


\section{LEGAL FRAMEWORK OF SEXUAL HARASSMENT}

In reality the creation of a single definition of sexual harassment as a universally acceptable in all countries is impossible, due to the diversified legal, sociological and psychological perspective, which is seen not only on the basis of cultural diversity, but also because of the presence of sex differences. „What is sexual harassment?" One of the basic dilemmas that arise when looking at sexual harassment in a particular context is whether to look at it from a legal or behavioral perspective. Essentially, it is much easier to use legal definitions, since they are narrower and more specific. As a result of that, we will continue to provide legal definitions of sexual harassment in culturally different countries.

The term sexual harassment emerged in the early 70 s of the last century, precisely in 1979 with Catherine MacKinnon book ,Sexual harassment of working women: The case of gender discrimination." 27 The author defines sexual harassment as: „Unwanted showing of sexual demands in the context of unequal power relations." 28 Since then, there have been a many improvements in the definition and the Employment Sexual Harassment Law, in order to protect employee's at the most adequate way. Today, there is a valid legal view that sexual harassment is a form of sexual discrimination, which consists of two forms of behavior: quid pro quo sexual harassment and hostile work environment sexual harassment. ${ }^{29}$ Quid pro quo sexual harassment occurs when someone seeks out sexual favors in return for job benefits of any kind - accolades, pay increase, more favorable hours, etc. ${ }^{30}$ On the other hand, hostile work environment sexual harassment implies a situation in which harassed individuals feel discomfort or intimidation, which impedes individual performance.

Looking at the European Union close to us, it is possible to claim that it has done a lot in terms of protecting employees from sexual harassment. The most European Union members had their sexual harassment laws, so it tried to harmonize differences. The initial impetus for the inclusion of sexual harassment was the Council Directive on the equal treatment of men and women in terms of employment, training and promotion, as well as working conditions (76/207/EEC). ${ }^{31}$ Later, for the sake of introducing the term sexual harassment, the Directive

${ }^{27}$ Catharine Alice MacKinnon, Sexual harassment of working women: A case of sex discrimination, Yale University Press, New Haven - London 1979.

28 „Refer.“ Miller v. Bank of America, 418 F. Supp. 233 (US District Court for the Northern District of California, 1976), revisited, 600 F.2d 211 (9th Cir. 1979).

${ }^{29} w w w$.freelegalaid.com/nav/massachusetts/employment-law/article/quid-pro-quo-andhostile-work-environment-sexual-harassment, 25. may 2018.

${ }^{30}$ Ibid.

31 „See in“ Council Directive 76/207/EEC, Official Journal L 039 , 14/02/1976 P. 0040 0042,1974., http://www.equalrightstrust.org/ertdocumentbank//council_directive_76207eec.pdf, 26. maj 2018. 
2002/73 / EC of the European Parliament, supplementing Directive 76/207 / EEC. ${ }^{32}$ Changes in the Council Directive on the equal treatment of men and women in terms of employment, training and improvement, as well as working conditions, are legally prescribed (Article 2, § 2), with introduces the definition of sexual harassment, followed by legal changes (Article 2, §5), which prescribes procedures for the prevention of sexual harassment, as well as the legal solution (Article 8 ), which prescribes the establishment of appropriate bodies for complaints of potential victims. ${ }^{33}$ According to the introduced changes (Article 2, §2), sexual harassment is defined as: „Sexual harassment occurs as any form of unwanted verbal, non-verbal or physical behavior of a sexual nature, with the aim or effect of violating the dignity of a person, especially when creating a scary, hostile, humiliating, degrading or offensive environment " 34

Considering that Serbia is not a member of the European Union, but for many years before now we have been trying to harmonize our domestic laws with the laws of the European Union, we will try to point out the solutions that have applied countries as possible role models. One of them is certainly Germany, which has become a dream for numerous medical personnel, informatics, and representatives of other professions. Germany is a long time the issue of sexual harassment defined as: „Any intentional, sexually oriented behavior that undermines the dignity of employees in the workplace," regulated in the National Laws on Labor, Social Security and Related Human Rights. ${ }^{35}$ However, after a series of harassing cases caused by the actions of large groups of immigrants, the Criminal $\mathrm{Law}^{36}$ was adopted with radical measures. According to the extended definition it is now defined as: ,any sexual act that a victim declines through verbal or physical cues, and other forms of non-consensual sexual contact, such as groping and fondling, were not illegal". ${ }^{37}$ According to the Criminal Law ${ }^{38}$ the penalties provided for various forms of sexual assault, sexual coercion and rape, range from 6 months to 10 years ${ }^{39}$ According to Article 184 sexual harassment is considered only

32 „See in“ Directive 2002/73/EC of the European Parliament, Official Journal L 269 , 05/10/2002 P. 0015 - 0020, https://eur-lex.europa.eu/legal-content/EN/TXT/?uri=celex\%3A32002L0073, 26. maj 2018.

${ }^{33}$ Ibid., 1318-1320.

${ }^{34}$ Ibid., 1325-1328.

${ }^{35}$ Act to establish equality for men and women (Second Equality Act - 2. GleiBG), Bundesgesetzblatt, 30 June 1994, No. 39, pp. 1406-1415., National Laws on Labor, Social Security and Related Human Rihts, http://www.ilo.org/dyn/natlex/docs/WEBTEXT/39143/64941/E94DEU02.htm, 25. Maj 2018.

${ }^{36}$ Strafgesetzbuch

${ }^{37}$ Tatjana Hörnle, „The new German law on sexual assault and sexual harassment”, German Law Journal 18(6), 2017., 1310-1330.

${ }^{38}$ Article 177.

${ }^{39}$ Tatjana Hörnle, „The new German law on sexual assault and sexual harassment”, German Law Journal 18(6), 2017., 1310-1330. 
physical touch, excluding non-verbal signs. ${ }^{40}$ The penalties range from two years or a certain monetary compensation.

Observing legal regulations of Austria regarding sexual harassment, we can freely argue that it is a highly regulated country. According to the Law on Equal Treatment (Private Sector), § 7 and $\S 8 \mathrm{a}$ of the Federal Law on Equal Treatment, sexual harassment is defined as: ,cconducts in the workplace by taking unwanted, inappropriate, offensive, humiliating or offensive sexual behavior that causes a scary, humiliating or hostile working environment." 41 At the same time, sexual harassment under the Criminal Code $\S 218$, is a criminal activity, which refers to a sexual act committed against the will of the victim, ${ }^{42}$ which negatively affects the dignity of the victim. So, it's about activities that relate both to the private and the business sphere.

Finally, data for one of the countries of the former Yugoslavia shows that it is strongly fighting against sexual harassment. It is about Croatia, which is in the Anti-Discrimination Act ${ }^{43}$, defined sexual harassment as , any verbal, non-verbal or physically undesirable behavior of a full nature, which is intended or actually constitutes a violation of the person's dignity, and in particular if it creates a scary, hostile, humiliating, degrading or offensive environment." 44 Sanctions for sexual harassment are quite high. According to Article 31 Law on Gender Equality, prescribed penalty for discrimination is equivalent to 670 to 5300 euros.$^{45} \mathrm{Nu}$ merous problems are solved by the fact that in every organization with more than 20 employees is an open mobbing office and in them is one person who is always open to receiving complaints.

Until 2005, the issue of sexual harassment has been neglected in Serbia, since it is a traditional environment which was rarely believed that a woman did not cause a male person by her behavior. The legal terminology for the first time in our country recognizes the concept of sexual harassment in the 2005 at the Labor Law Republic of Serbia ${ }^{46}$, defining it as: ,, any verbal, non-verbal or physical conduct that aims or constitutes a violation of the dignity of a person seeking employment, as well as an employee in the field of sex life who causes fear or creates an enmity, degrading or offensive environment". ${ }^{47}$ In 2010 comes into force

\footnotetext{
${ }^{40}$ Ibid.

${ }^{41}$ https://www.ris.bka.gv.at/Dokumente/Bundesnormen/NOR40100109/NOR40100109.pdf-

${ }^{42}$ https://www.ris.bka.gv.at/Dokumente/Bundesnormen/NOR40093007/NOR40093007.pdf, Strafrechtsänderungsgesetz 2015, went into effect on Jan 1 2016, 21. may 2018.

${ }^{43}$ Article 3.

${ }^{44}$ https://zakon.hr/z/490/Zakon-o-suzbijanju-diskriminacije, 21. may 2018.

${ }^{45}$ https://www.zakon.hr/z/388/Zakon-o-ravnopravnosti-spolova, 21. may 2018

${ }^{46}$ Article 21.

${ }^{47}$ Labor Law, "Official Gazette of the Republic of Serbia”, Nos. 24/2005, 61/2005, 54/2009, 32/2013, 75/2014 and 13/2017 - decision of the CC
} , 20. maj 2018. 
the Law on Prevention of Harassment at Work, which in Art. 3, prohibits sexual harassment, and in Art. 35, prescribes a criminal provision for the employer in the amount of 200,000-800,000 dinars. ${ }^{48}$ Finally, the latest version Criminal Code of the Republic of Serbia in Art. 182a clearly defined that is sexual harassment: ,any verbal, non-verbal or physical conduct that is aimed at or constitutes a violation of the dignity of a person in the field of sexual life that causes fear or creates an enmity, degrading or offensive environment." 49

According to the Law on Prevention of Harassment at Work, the subject of harassment can initiate: 1. internal procedure of protection against harassment, together with the employer; and 2. Submit a court notice. In addition, the rule is that from the moment of submission of the complaint until its delivery to the employer, if the internal procedure is initiated, it must pass the maximum of three days. Today, almost all larger companies have a person, who is responsible for the issue of harassment. Realistically, for a person who is harassed, it would be better if she can arrange with employer. Unfortunately, judicial proceedings often last very long, and even if they end up in favor of the harassed persons, there is a little chance that the employer will return employees to the work. Similarly, monetary compensation is almost as a rule not paid off. Unfortunately, the job market is full of individuals who are looking for a job, so it's very easy to find a replacement. As a result, most employers are not much interested in finding employees at the labor market. It's a completely different situation with the persons, without whose knowledge, skills and general abilities, the organization's business activities could not be implemented. ${ }^{50}$

\section{BEHAVIORAL ASPECTS OF SEXSUAL HARASSMENT}

Considering sexual harassment it has been pointed out that there are numerous aspects of his observation from the legal through behavioral, psychological, social and other. In the continuation of the paper will be pointed out on behavioral aspects and the appropriate organizational context. One of the definitions that indicate behavioral aspect is: ,sexual harassment is the inappropriate behavior that occurs in traditionally male professions." ${ }^{51}$ In the continuation of the work, a model of sexual harassment will be presented, which will points to all behavi-

\footnotetext{
${ }^{48}$ Law on the Prevention of Harassment at the Workplace, "Official Gazette of the Republic of Serbia", Nos. 36/10.

${ }^{49}$ Criminal Code, "Official Gazette of the Republic of Serbia”, Nos. 85/2005, 88/2005 - cor., 107/2005 - cor., 72/2009, 111/2009, 121/2012, 104/2013, 108/2014 and 94/2016).

${ }^{50}$ Goran D. Milošević „Faktori promena na tržištu radne snage Srbije”, Zbornik radova PFNS 3/2017, 713-735, 714.

${ }^{51}$ Barbara Gutek, Aaron Grof Cohen, and Alison Konrad, „Predicting social-sexual behavior at work: A contact hypothesis”, Academy of Management Journal, 33.3, 1990, 560-577, 562.
} 
oral aspects in the organizational context. In it model was given second definition of sexual harassment as ,,a means by which perpetrators, using their powers, achieve the desired outcomes or obtain the desired resources." 52 (Shown in Figure 1).

Aggressor undertakes sexually interconnected actions, expecting to impose harm to another person or obtain his / her consent, in order to achieve personally valued goals. The goal of the aggressor who engages in sexual harassment is to satisfy personal sexual aspirations "re-victimize" the victim, and create fear of retribution, anger, disappointment, alienation, and disgust, physical and psychological abuse. Aggressor behaves in this way for two reasons. According to the first, personal inability to dealt with a problem and solve it represent unpleasant experiences, which caused a frustration and aggressor try to the injuries of innocent others. According to another, the aggressor seeks to establish and maintain positive images of him in the work environment, in order to achieve more social power.

The victim's perception of sexual harassment will affect later emotional and behavioral responses. Interestingly, sexual harassment is not always seen as aggressive by the victim. If sexual harassment and abuse is common, they become normative and are less likely to be challenged by the individual. Likewise, if the victim estimates that there is only one attack, which will not appear in the future, the event will be ignored.

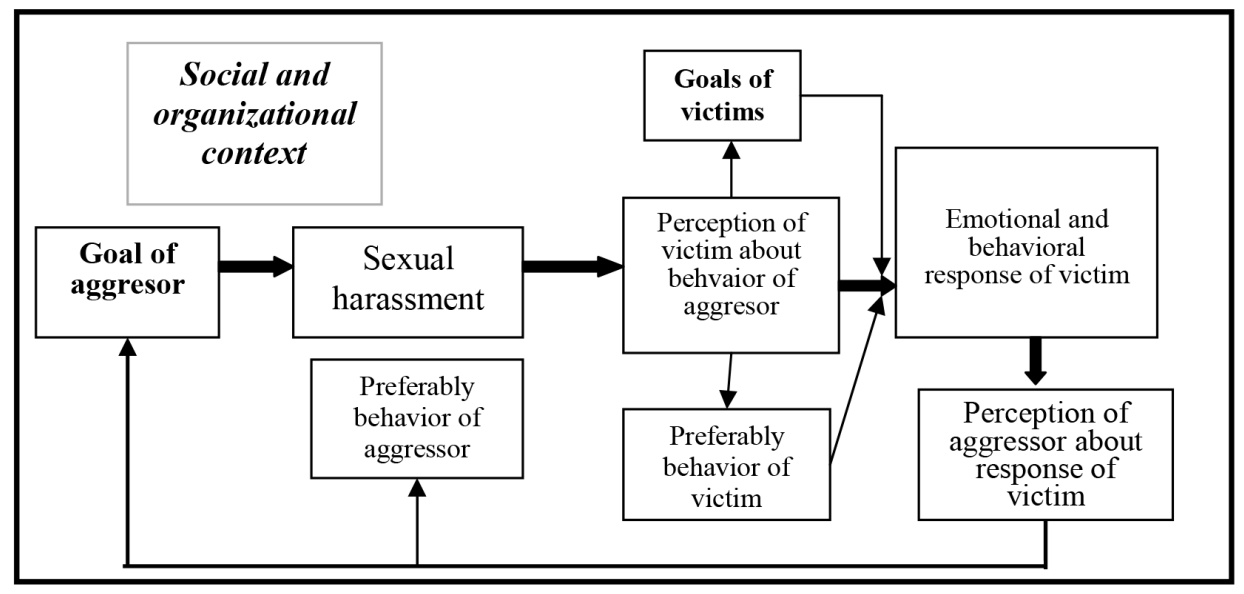

Picture $1^{53}$

Preferred behavior of the victim was attempted to be modeled through numerous research. In this respect, it is said that the victim must learn: (a) to oppose

${ }^{52}$ Anne O'Leary-Kelly, Ramons Paetzold and Ricky Griffin, ,Sexual harassment as aggressive behavior: An actor-based perspective”, Academy of Management Review, 25(2), 2000, 372-388, 373-374.

${ }^{53}$ Ibid., 374. 
harassment, (b) to share his feelings about harassment, and (c) tell the harasser, in very explicit terms, that he / she wants that stop disturbing behavior. ${ }^{54}$ Emotional and behavioral responses will appear if the victim feels threatened. ${ }^{55}$ Internal behavioral responses are: lessening of importance, endurance, denial, redirection and self-indulgence. External behavioral responses are: avoidance, social support, confrontation, institutional and organizational struggle and relaxation.

Finally, the organizational context encourages sexual harassment if: 1) the organization does not have preventive guidelines and avoids serious consideration of victims' complaints, 2) women are part of a non-traditional atmosphere, 3) the organization maintains an inequitable gender relationship, and 4) there is a role model (if individuals notice that the behavior of sexual harassment of other men is acceptable). ${ }^{56}$

Thus, the model of sexual harassment completely illuminated the second approach to such a complex concept, indicating that sexual harassment cannot be presented by looking at only one aspect. At the same time, he supported the legal provisions in Serbia, pointing out that the introduction of institutional and organizational struggle was the only way for the legal solution of sexual harassment.

\section{EMPIRICAL RESEARH}

The research was conducted with the aim of checking the following hypotheses:

H0: There is no statistically significant correlation between the dimensions of sexual harassment and personal business performance among members of different sexes.

H1: There is a statistically significant correlation between the dimensions of sexual harassment and personal business performance among members of different sexes.

The first study that examined the impact of dimensions of sexual harassment on (not the same ones that are the subject of this paper) the psychological and physical health (not on the basis of the same hypothesis and not on the same sample), was conducted in January-March 2017 in three private companies, but only on a sample of 180 women. The results showed that sexual disturbing and sexual coercion significantly endanger the mental and physical health, as well as business

\footnotetext{
${ }^{54}$ Merle Waxman, „Constructive responses to sexual harassment in the workplace”, Employee Responsibilities and Rights Journal 7.3, 1994, 243-246, 244.

${ }^{55}$ Ibid as 33, p. 376.

${ }^{56}$ Louise Fitzgerald, Fritz Drasgow, Charles Hulin, Michele Gelfand, and Vicki Magley, „Antecedents and consequences of sexual harassment in organizations: A test of an integrated model", Journal of Applied psychology 82. 4, 1997, 578 -589, 587.
} 
performance. ${ }^{57}$ More precisely, sexual coercion according to results of research has $100 \%$ influence on mental health, and a sexual disturbance about $60 \%$ on physical health. However, it is now trying to look at the position of men regarding sexual harassment. More precisely, "Do men also show such a degree of sensitivity or is it culturally necessary for men to take the first steps toward women in Serbia?"

Empirical research with the intention of examining hypotheses was conducted on a sample of 323 women and 242 men in 5 organizations in the period September - December 2017. Three companies were privately owned and two stateowned. The first company Dehleze, was the subject of a survey in Belgrade and Novi Sad. It covered 47 women and 32 men. Another private company Idea included a sample of 96 women and 63 men in Belgrade, Cacak and Smederevo. In the third company Meat Industry Topola, 6 women and 5 men were surveyed in the area of Belgrade and Backa Topola. State enterprise Post of Serbia has allowed interviewing 121 women and 91 men in Belgrade, Uzice and Cacak. Finally, the Electric Power Industry of Serbia included a survey of 53 women and 51 men in the territory of Belgrade and Kraljevo.

The first part of the research, which was not directly related to the hypotheses, were that the respondents answered on the question "Were they victims of sexual abuse?". The results are shown in Fig. 2.

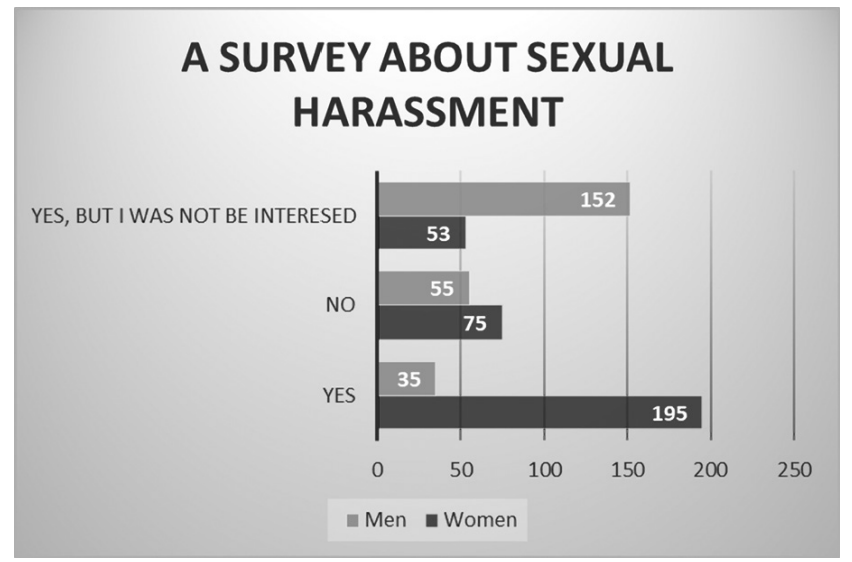

Picture 2

The second part of the study determined the degree of correlation between business performance and physical on the one hand, as well as verbal and nonverbal sexual harassment on the other. The research was carried out using the Likert type questionnaire, where 1 was no, and 3 -yes. Business performance

${ }^{57}$ Ivana Erić i Slavica Dabetic, ,Seksualno zlostavljanje žena na poslu u Srbiji“, 18. International Conference Accounting and Management - A and M, 21.-22. septembar, 2017, 43-79. 
was also examined using a Likert type survey, in which 1 meant no, 2 - moderately and 3 - to a large extent. The SPSS program was used in data processing. The strength and direction of connection between the two groups of variables ranges from -1 to 1. Pearson or Spearman coefficient of correlation will be used to test the existence, direction, and strength of the connection, depending on the way the data was distributed. The correlation was measured using Spearman's correlation coefficient $(\boldsymbol{\rho})$, since there is no normal distribution between variables. The statistical significance of the obtained values of the coefficients is determined on the basis of $p$-values. More precisely for all $\boldsymbol{p}<0.05$ values, one can accept the existence of a statistically significant correlation between the observed sets of variables. Results are shown in Table 1.

Table 1. Correlation between dimensions of sexual harassment and business performance between different genders

\begin{tabular}{|c|c|c|c|}
\hline Gender & Dimensions of sexual harassmenr & & Business performance \\
\hline \multirow{6}{*}{ Women } & \multirow{3}{*}{ Phycical } & $\rho$ & $.645^{* *}$ \\
\hline & & $p$ & .000 \\
\hline & & $\mathbf{N}$ & 323 \\
\hline & \multirow{3}{*}{ Verbal and nonverbal } & $\rho$ & .103 \\
\hline & & $p$ & .407 \\
\hline & & $\mathbf{N}$ & 323 \\
\hline \multirow{6}{*}{ Mens } & \multirow{3}{*}{ Physical } & $\rho$ & .023 \\
\hline & & $p$ & .853 \\
\hline & & $\mathbf{N}$ & 242 \\
\hline & \multirow{3}{*}{ Verbal and nonverbal } & $\rho$ & .154 \\
\hline & & $p$ & .214 \\
\hline & & $\mathbf{N}$ & 242 \\
\hline
\end{tabular}

Based on the results of the conducted research, we can freely argue that the alternative hypothesis is partially confirmed. More specifically, it was determined that there was a high positive correlation between the physical dimension of sexual harassment and business performance among women $(\rho=0.645 ; p=0)$. Namely, according to the results of the research, if women experience physical sexual harassment at work, then there will be a significant decline in business performance.

In all other situations, it is not possible to accept an alternative hypothesis. More precisely, statistically significant interdependencies have not been established between verbal and nonverbal sexual harassment, as well as business performance among women, which does not mean that they do not exist $(\mathrm{p}=0.407)$. There is also no basis to accept an alternative hypothesis for male members, since $\mathrm{p}$ values for all dimensions are greater than $0.05(p=0.853 ; p=0.214)$. Of course, the conducted research did not investigate the influence of sexual harassment 
male vs. male, which does not imply the absence of such relations. It would appear that men are insensitive to sexual harassment, observing the results of the research. However, the research in the world shows that there are a relatively large number of reports of sexual harassments among men. In the case of Serbia, it may be that male members probably do not perceive certain forms of behavior as sexual harassment or they don't want to report it.

\section{CONCLUSION}

The paper focuses on the impact of sexual harassment on the business results of the company in Serbia with respect to legal and behavioral aspects. The chronological monitoring of the improvement of legal regulations since 2005, until the formulation of sexual abuse as a crime in 2017, has been carried out. Such tendency, fully demonstrates the readiness of the legal system in Serbia to protect workers at least in the mentioned segment.

Analysis of legal regulations on sexual harassment in Serbia began by comparing with regulations in Anglo-Saxon law, primarily in the United States on whose ground it was observed. Furthermore, the basis of legal regulation in the European Union was showed, whose member we are trying to become-Germany, as the most developed country and Austria, in which the most of our citizens want to work. Finally, the comparison was done with Croatia, as the former Yugoslav Republic, with the intention to determine in which extent they are more rigorous than Serbia.

The second part of this paper deals with the behavioral aspects of sexual harassment, since it is not possible to find separate legally from a behavioral dimension. The authors of the paper can freely argue that the organizational context is a key dimension for the extent of sexual harassment in a particular organization.

Finally, a small survey was conducted to determine the presence of sexual harassment at the "field" and its impact on business performance. Previous research has shown that the dimensions of sexual harassment have significant impact on the performance of women. As a result, a study was conducted in order to determine the impact of dimensions of sexual harassment on the performance of both men and women. It was found that the only statistically significant link exists between the physical sexual harassment of women and the decline in business performance.

Statistical significance at male regarding the impact of dimensions of sexual harassment on business results has not been proven. Further research could move towards the number of applications for sexual abuse at work in Serbia, their validity (i.e. "false alarms" for the achievement of other goals), the number of positive or rejected court judgments and the time period that needed to be adjudicate. 
Др Звездан М. Ђурић, ванредни ирофесор

Универзитетей у Прищитини

Економски факулиетеи Косовска Мийровииа

zvezdan.djuric@bbs.edu.rs

Др Ивана М. Ерић, ӣрофесор стируковних сӣудија

Беооградска йословна щикола

ivana.eric@bbs.edu.rs

\section{Утицај сексуалног злостављања на пословне резултате предузећа у Србији Правно - бихејвиорални аспекти}

Сажейак: Сексуално злостиављање на раду ӣредсииавља један од највећих сииресора, односно дог̄ађаја, који може йореметиийи йојединце у нормалном функиионисаюу, обавезно захиеевајући иеелесна, йсихолощка или бихејвиорална йрилаг̄ођавања, чиме може изазваиии бројне йоследице. Поседује ирравну, моралну и бихејвиоралну димензију. Услед йог̄a, у раду су ирезениииране ирравне дефинииије, йоједине моралне дилеме и бихејвиоралне имииликације. Свакако, йосмайрано из уг̆ла йословних имйликација сексуално злостиављање остиавља негайивне йсихолощке и ойщие здравстивене йоследиче, као и значајан йад йословних иерформанси. Прейознавағем йоменуйог йроблема савремене светиске оргіанизаиије, иируде се да га искорене. Међуйим, у многимм иррадиционалним срединама, којима ирийада и наши, ирроблемайика дуг̄и низ гоодина није размайрана као значајна. Током 2005. године, Чланом 21 Закона о раду РС бива забрањено сексуално злостиављаюе у нашој земли, чиме је йоказана добра воља за искорењивањем йако ружне ирраксе. У раду је сироведено емйиријско истираживање са намером

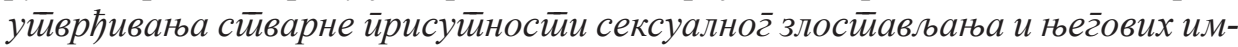
йликачија на йословне иеррформансе орг̄анизација.

Кључне речи: сексуално злостиављање, ирравна рег̄улайива, здравстивене йоследице, йад йословних иеррорманси.

Датум пријема рада: 04.06.2018. 